\title{
Use of Mouse Anti-Rabies Monoclonal Antibodies in Postexposure Treatment of Rabies
}

\author{
Carolin L. Schumacher, Bernhard Dietzschold, Hildegund C. J. Ertl, Hong-Shun Niu, \\ Charles E. Rupprecht, and Hilary Koprowski \\ The Wistar Institute, Philadelphia, Pennsylvania 19104
}

\begin{abstract}
Immunization of mice and hamsters with a cocktail of mouse MAbs specific for rabies virus nucleocapsid protein and glycoprotein protected animals not only when challenged with a lethal dose of rabies virus after immunization, but also in postexposure situations. Hamsters treated with the MAb cocktail $3 \mathrm{~h}$ after virus inoculation were completely protected from lethal rabies virus infection, and $80 \%$ of the animals survived when the MAb cocktail was given $36 \mathrm{~h}$ after virus challenge. The potential usefulness of this MAb cocktail for the postexposure treatment of human rabies is discussed.
\end{abstract}

\section{Introduction}

Rabies remains a significant human disease throughout the developing world; for example, $\sim 500,000$ persons (1) undergo antirabies treatment, and in India some 40,000-50,000 people are reported to die of rabies each year (2).

Effective postexposure treatment of rabies as recommended by the World Health Organization includes the prompt use of human or equine anti-rabies immunoglobulins (HRIG or ERIG, respectively), ${ }^{1}$ together with the administration of rabies vaccine. Animal experiments have demonstrated that treatment with vaccine alone does not prevent lethal rabies virus infection in postexposure situations $(3,4)$. Antirabies antibodies appear to be an essential component in the treatment of rabies; however, the precise role of such antibodies in postexposure treatment is unclear. Possible mechanisms whereby rabies virus-neutralizing antibodies (VNA), solely directed against the rabies virus glycoprotein ( $G$ protein), exert their effect, include neutralization of extracellular rabies virus, complement-mediated lysis of rabies virus-infected cells, and antibody-dependent cellular cytotoxicity (5). In addition, other antibodies, including those directed against the internal nucleocapsid protein (RNP) of rabies virus, are capable of regulating the immune response of $\mathrm{T}$ lymphocytes (6). Anti-

Address reprint requests to Dr. Bernhard Dietzschold, The Wistar Institute, 36th Street at Spruce, Philadelphia, PA 19104.

Received for publication 27 March 1989.

1. Abbreviations used in this paper: CVS, challenge virus standard; ERA, Evelyn-Rokitnicki-Abelseth; ERIG, equine anti-rabies immunoglobulin; GMT, geometric mean titer; G-protein, glycoprotein; HRIG, human anti-rabies immunoglobulin; PM, Pitman-Moore; RNP, ribonucleoprotein; VNA, virus neutralizing antibody.

J. Clin. Invest.

(C) The American Society for Clinical Investigation, Inc.

$0021-9738 / 89 / 09 / 0971 / 05 \$ 2.00$

Volume 84, September 1989, 971-975 bodies that recognize the G protein or RNP proteins were recently shown to play an important role in potentiating the antigen-induced proliferative response of rabies virus-specific $T$ lymphocytes and their production of IFN- $\gamma$, shown to be involved in the protection against lethal rabies virus infection (7).

Because of the adverse effects ranging from local reactions at injection sites to anaphylaxis connected with the use of ERIG (8), only HRIG is ideally recommended for postexposure treatment of humans. However, because of the high cost of HRIG and the high incidence of human rabies exposures, there is often insufficient amounts of HRIG available to complete the full recommended postexposure treatment. Limited access to HRIG is probably a major contributing factor in the increasing number of postexposure treatment failures $(9,10)$. Additionally, safety aspects of human immune serum treatment must be considered, due to the potential risk of hepatitis $B$ virus and human immunodeficiency virus contamination. In this paper, we describe the use of mouse MAbs in the postexposure treatment of rabies in mice and hamsters. It has been shown in humans that mouse MAbs, although being xenogenic, bear a low risk of severe allergic reactions (11). To obtain the identical or similar activities found in HRIG, several MAbs were selected to meet the following criteria: $(a)$ the MAbs should be of IgG isotype, because IgM antibodies are not effective in vivo (12); and (b) the majority of these MAbs should recognize the $G$ protein and neutralize a broad spectrum of rabies and rabies-related virus strains. These G-specific antibodies must differ in their epitope specificities to prevent the escape of neutralization-resistant variants. (c) Some MAbs should recognize the internal RNP protein of rabies virus. This cocktail, consisting of rabies $G$ protein and RNPspecific mouse MAbs is highly effective in the postexposure treatment of rabies in infected mice and hamsters.

\section{Methods}

The challenge virus standard (CVS), Evelyn-Rokitnicki-Abelseth (ERA), and Pitman-Moore (PM) strains of fixed rabies virus as well as street rabies virus isolates and the rabies-related Duvenhage and Mokola viruses were propagated in BHK-21 cell culture monolayers as previously described (13).

MAbs. Hybridomas that secrete MAbs specific for rabies $\mathrm{G}$ protein and RNP were produced by the fusion of $\mathrm{P} 3 \times 63 \mathrm{Ag} 8$ or 654 myeloma cells with splenocytes of $B A L B / c$ mice immunized with several strains of rabies virus (14).

Purification of MAbs. MAbs were precipitated from ascites fluid with $\left(\mathrm{NH}_{4}\right)_{2} \mathrm{SO}_{4}$ as described (15). The precipitate was dissolved in PBS dialyzed against $25 \mathrm{mM} \mathrm{2-(} N$-morpholino)ethanesulfonic acid (MES), pH 5.5, and subjected to HPLC ion exchange chromatography using a $15-\mu \mathrm{m}$ column (Baker Bound Abx Prep; Baker Chemical Co., Philipsburg, NJ). Chromatography conditions were similar to those previously described (16): solvent A was $25 \mathrm{mM}$ MES, pH 5.6, and solvent 
B was $1 \mathrm{M}$ sodium acetate, $\mathrm{pH}$ 7.0. A gradient of 0-70\% $\mathrm{B}$ was run for $60 \mathrm{~min}$ at a flow rate of $3 \mathrm{ml} / \mathrm{min}$ at ambient temperature. The elution of proteins was monitored by UV absorbance at $280 \mathrm{~nm}$. Peak fractions containing the MAb were pooled, dialyzed against PBS, and concentrated by ultrafiltration.

Preparation of $F\left(a b^{\prime}\right)_{2}$. F $\left(a b^{\prime}\right)_{2}$ fragments were prepared from purified MAbs as described (17). $15 \mathrm{mg}$ of MAb in $10 \mathrm{ml} 0.1 \mathrm{mM}$ sodium acetate buffer, $\mathrm{pH} 4.5$, were mixed with $0.15 \mathrm{mg}$ of pepsin (Millipore Corp., Bedford, MA) and incubated at $37^{\circ} \mathrm{C}$ for $16 \mathrm{~h}$. The digest was dialyzed against PBS and subjected to chromatography on a protein A-Sepharose CL-4 B column (Pharmacia Fine Chemicals, Piscataway, $\mathrm{NJ})$. No residual intact $\mathrm{IgG}$ was detectable in the $\mathrm{F}\left(\mathrm{ab}^{\prime}\right)_{2}$ preparation when analyzed by SDS-PAGE.

Virus neutralization assay. A modification of the rapid fluorescent focus inhibition test was performed as previously described (18). A reduction of viral titer by $>100$ infective units was considered as positive virus neutralization.

In vivo protection experiments in mice. 6-wk-old female white Swiss mice (Harlan Sprague-Dawley, Inc., Indianapolis, IN) in groups of 7 or 10 were injected intramuscularly into the right gastrocnemius muscle with $0.1 \mathrm{ml}$ of one of five serial dilutions (100-0.16 IU) of mouse MAbs. At $24 \mathrm{~h}$ after MAb treatment, all mice were inoculated intramuscularly in the left gastrocnemius muscle with $10^{6}$ mouse intracerebral (MIC) LD so $_{50}$ CVS-24 virus. Animals were observed for $3 \mathrm{wk}$ and deaths were reported daily. The effective dose $\left(E^{2} D_{50}\right)$ of MAbs was calculated as described (19).

Postexposure treatment of hamsters with mouse MAbs. 4-6-wk-old Syrian hamsters (Harlan Sprague-Dawley, Inc.) were used for all experiments. Challenge virus consisted of a $20 \%$ salivary gland suspension of a street rabies virus isolate of fox origin; dilutions were made in distilled water containing $2 \%$ horse serum. For each trial, hamsters were divided into groups of five and received $100 \mu \mathrm{l}$ of MAbs, as

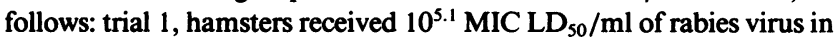
the left gastrocnemius muscle, and 3 or $36 \mathrm{~h}$ later, 1,550 IU/kg MAbs at the same site; trial 2, hamsters received $10^{4.6} \mathrm{MIC} \mathrm{LD}_{50} / \mathrm{ml}$ of rabies virus in the left gastrocnemius muscle, and $2 \mathrm{~h}$ later, $155 \mathrm{IU} / \mathrm{kg}$ MAbs at the same site.

Animals were examined daily for definitive clinical signs of rabies infection and were euthanized when in extremis by $\mathrm{CO}_{2}$ intoxication. Survivors were followed for at least $\mathbf{3 0} \mathrm{d}$ after rabies virus inoculation, at which time they were similarly euthanized. Control hamsters received $100 \mu \mathrm{l}$ of PBS.

\section{Results}

Selection of MAbs for pre- and postexposure prophylaxis of rabies. 5 MAbs were selected from a panel of 76 specific for rabies virus $G$ protein and $R N P$ on the basis of: isotype, antigen, and epitope specificity, virus strain specificity, affinity, and virus-neutralizing activity (Table I). Three of the five MAbs were specific for the $G$ protein and the other two nonneutralizing MAbs were specific for RNP. Each of the three $G$ protein-specific antibodies recognizes a different epitope on the $G$ protein, and all three $G$ protein-specific MAbs neutralize in vitro all fixed rabies virus strains and most street rabies virus isolates (20). In addition, MAb 1112-1 neutralized the rabiesrelated strain Duvenhage, whereas MAb 523-11 neutralized Mokola virus (18).

Despite the broad range in virus neutralizing activity, of the three $G$ protein-specific MAbs, $(1,667,61$, and 8,242 IU/mg for MAbs 509-6, 1112-1, and 523-11, respectively), the specific virus-neutralizing activity of each of these MAbs was superior to that of HRIG (1.13 IU/mg protein).

The RNP-specific MAbs 802-1 and 502-2 recognize different epitopes on the $N$ protein but do not have neutralizing activity in vitro (20). The MAb 502-2 reacts with all known rabies and rabies-related virus strains (20), and MAb 802-1 recognizes most rabies strains (18).

When all five MAbs were used as a mixture, the specific virus-neutralizing activity of the cocktail was $1,376 \mathrm{IU} / \mathrm{mg}$ protein.

Protective activity of MAbs in mice. The prophylactic efficacy of individual MAbs was determined. Various dilutions of the MAbs were inoculated intramuscularly into mice, followed $24 \mathrm{~h}$ later by a lethal dose of the CVS-24 strain of rabies virus. Whereas pretreatment of mice with the RNP-specific MAbs had no effect on survivorship (data not shown), administration of the $\mathrm{G}$ protein-specific MAbs $24 \mathrm{~h}$ before challenge effectively prevented a lethal rabies virus infection (Table II). 2 IU of MAb 509-6 and 2.36 IU of MAb 523-11 were necessary to protect $50 \%$ of mice. Although the in vitro virus-neutralizing

Table I. Characteristics of MAbs Used in this Study

\begin{tabular}{|c|c|c|c|c|}
\hline MAb No. & Isotype & $\begin{array}{c}\text { Antigen and } \\
\text { epitope specificity }\end{array}$ & $\begin{array}{l}\text { Specific } \\
\text { virus-neutralizing } \\
\text { activity }\end{array}$ & Virus strain specificity \\
\hline & & & $I U / m g$ & \\
\hline $509-6$ & $\gamma 2 a$ & G site I & 1,667 & $\begin{array}{l}\text { Neutralization of all fixed and street rabies virus strains except some } \\
\text { virus isolates from bats }\end{array}$ \\
\hline $1112-1$ & $\gamma 1$ & G site IIc & 61 & $\begin{array}{l}\text { Neutralization of all fixed and street rabies virus strains and the } \\
\text { rabies-related Duvenhage strains } 1-6\end{array}$ \\
\hline 523-11 & $\gamma 2 a$ & G site IIb & 8,242 & $\begin{array}{l}\text { Neutralization of all fixed and street rabies virus strains except some } \\
\text { street virus isolates from bats and foxes, neutralization of rabies- } \\
\text { related Mokola } 3\end{array}$ \\
\hline $802-1 \mathrm{~g}$ & $\gamma 2 \mathrm{~b}$ & $\mathbf{N}$ site II & 0 & $\begin{array}{l}\text { Binding to all fixed and street rabies virus strains and some rabies- } \\
\text { related viruses }\end{array}$ \\
\hline $502-2$ & $\gamma 2 a$ & $\mathrm{~N}$ site III & 0 & Binding to all rabies and rabies-related viruses \\
\hline MAb cocktail* & & $\mathrm{G}, \mathbf{N}$ & 1,376 & ND \\
\hline
\end{tabular}

* The MAb cocktail represents a mixture of $112.5 \mathrm{IU} / \mathrm{ml}$ MAb 509-6, $10 \mathrm{IU} / \mathrm{ml}$ of MAb 1112-1, $800 \mathrm{IU} / \mathrm{ml} \mathrm{MAb} 523-11,0.04 \mathrm{mg} / \mathrm{ml} \mathrm{MAb}$ $802-1$, and $0.6 \mathrm{mg} / \mathrm{ml} \mathrm{MAb} \mathrm{502-2}$ 
Table II. Passive Protection of ICR Mice with $G$ Protein-specific MAbs

\begin{tabular}{|c|c|c|c|c|}
\hline \multirow[b]{2}{*}{ MAb dose } & \multicolumn{4}{|c|}{ Mortality* } \\
\hline & MAb 1112-1 & MAb 509-6 & MAb 523-11 & $\mathrm{F}\left(\mathrm{ab}^{\prime}\right)_{2} 523-11$ \\
\hline \multicolumn{5}{|l|}{$I U$} \\
\hline 100 & - & - & $0 / 10$ & $2 / 11$ \\
\hline 20 & - & $1 / 10$ & $2 / 11$ & $7 / 10$ \\
\hline 4 & $0 / 10$ & $3 / 10$ & $8 / 10$ & $10 / 10$ \\
\hline 0.8 & $1 / 10$ & $7 / 10$ & $10 / 10$ & $10 / 10$ \\
\hline 0.16 & $0 / 10$ & - & - & - \\
\hline 0.032 & $2 / 10$ & - & - & \\
\hline $\mathrm{ED}_{50}$ & $<0.03$ & 2.0 & 2.36 & 34.00 \\
\hline
\end{tabular}

* Mice were challenged intramuscularly with $5 \times 10^{6} \mathrm{MIC} \mathrm{LD}_{50}$ of CVS $1124 \mathrm{~h}$ after MAb treatment.

activity of MAb 1112-1 was low, its protective activity in vivo was extremely high; as little as $0.03 \mathrm{IU}$ of this MAb were sufficient to prevent a lethal rabies virus infection in $50 \%$ of the animals. The basis of the discrepancy between in vivo and in vitro activity of MAb 1112-1 is not clear, but it is likely that the mechanisms by which MAbs act in vivo are very complex and involve more than neutralization of extracellular virus. The $\mathrm{ED}_{50}$ using $\mathrm{F}\left(\mathrm{ab}^{\prime}\right)_{2}$ fragments of MAb 523-11 was $34.0 \mathrm{IU}$ compared with $2.36 \mathrm{IU}$ for the intact $\mathrm{MAb}$, suggesting the importance of the Fc-containing region for in vivo protection.

To determine whether the time period between MAb treatment and virus inoculation influenced the protective activity of the antibodies, mice were pretreated with the MAb cocktail at different times before introduction of rabies virus. The $\mathrm{ED}_{50}$ of the MAb cocktail was $0.8 \mathrm{IU}$ when administered $24 \mathrm{~h}$ before challenge, but increased to 2.36 when the MAbs were given $2 \mathrm{~h}$ before challenge. Moreover, when the MAb cocktail was injected $2 \mathrm{~h}$ after inoculation, 42.8 IU were necessary to protect $50 \%$ of the mice (Table III).

Effect of site of virus challenge on MAb efficacy. Groups of mice were treated with dilutions of the MAb cocktail and $24 \mathrm{~h}$ later inoculated intracerebrally, or intrafootpad with a lethal dose of rabies virus. Treatment of mice with MAbs had vir-

Table III. Passive Protection of ICR Mice with MAb Cocktail

\begin{tabular}{cccc}
\hline & \multicolumn{3}{c}{ Mortality } \\
\cline { 2 - 4 } MAb dose & $\begin{array}{c}\text { MAb cocktail } \\
\text { 24 h before challenge }\end{array}$ & $\begin{array}{c}\text { MAb cocktail } \\
\text { 2 h before challenge }\end{array}$ & $\begin{array}{c}\text { MAb cocktail } \\
\text { 2 h after challenge }\end{array}$ \\
\hline$I U$ & & & \\
100.0 & $0 / 10$ & $0 / 7$ & $3 / 7$ \\
20.0 & $0 / 10$ & $1 / 10$ & $8 / 10$ \\
4.0 & $0 / 10$ & $4 / 10$ & $8 / 10$ \\
0.8 & $5 / 10$ & $7 / 10$ & $9 / 10$ \\
0.16 & $10 / 10$ & - & - \\
ED $_{50}$ & 0.80 & 2.36 & 42.80 \\
\hline
\end{tabular}

Mice were challenged intramuscularly with $5 \times 10^{6} \mathrm{MIC} \mathrm{LD}_{50}$ of CVS 24.
Table IV. VNA Titers and Mortality Rates after MAb Treatment or Immunization with BPL-inactivated ERA Virus

\begin{tabular}{cccc}
\hline \multicolumn{1}{c}{ MAb treatment* } & \multicolumn{3}{c}{$\begin{array}{c}\text { Immunization with } \\
\text { EPL-ERA }^{\ddagger}\end{array}$} \\
\hline $\begin{array}{l}\text { VNA titer } \\
(\mathrm{GMT}, n=7)\end{array}$ & Mortality & $\begin{array}{c}\text { VNA titer } \\
(\mathrm{GMT}, n=7)\end{array}$ & Mortality \\
$3,992(2,430-7,290)$ & $6 / 7$ & $768(90-3,125)$ & $1 / 7$ \\
\hline
\end{tabular}

* Mice were treated with $200 \mathrm{IU}$ of MAb cocktail and $24 \mathrm{~h}$ later, challenged intracerebrally with $5 \times 10^{4} \mathrm{MIC} \mathrm{LD}_{50}$ of CVS 11 .

${ }^{\ddagger}$ Mice were immunized with $2 \mu \mathrm{g}$ of BPL-inactivated ERA virus on day 0 and 7 and challenged on day 14 intracerebrally with $5 \times 10^{4}$ MICLD $_{50}$ of CVS 11.

${ }^{\S}$ Mice were bled $2 \mathrm{~h}$ before challenge.

tually no effect on mortality after intracerebral inoculation; even when $200 \mathrm{IU}$ of MAb were administered $24 \mathrm{~h}$ before intracerebral inoculation only one of seven mice survived. The ineffectiveness of MAb treatment against an intracerebral virus inoculation is puzzling because mice that received 200 IU of MAbs had a circulating VNA geometric mean titer (GMT) of 3,992 $24 \mathrm{~h}$ after injection but were not protected, whereas mice immunized with $\beta$-propiolactone inactivated rabies virus had a circulating VNA GMT of only 767 but survived intracerebral inoculation (Table IV). When mice were inoculated intrafootpad, $4 \mathrm{IU}$ of MAb cocktail administered $24 \mathrm{~h}$ before challenge were necessary to protect $50 \%$ of mice (not shown). Thus, the $\mathrm{ED}_{50}$ of MAbs against intrafootpad challenge is five times higher than that of the same MAbs against intramuscular challenge.

Efficacy of MAbs in the postexposure treatment of rabies in hamsters. Because most pathogenic rabies virus strains have a very short incubation time in mice (onset of clinical signs is 5-6 d after infection), it is difficult to perform postexposure treatment experiments in mice. The incubation period in hamsters is much longer (10-14 d), allowing the use of these animals as an alternative model for post-exposure treatment experiments. Five hamsters inoculated intramuscularly with rabies street virus were treated 2,3 , and $36 \mathrm{~h}$ after infection intramuscularly with 1,550 or $150 \mathrm{IU} / \mathrm{kg}$ of the MAb cocktail. The data in Table $\mathrm{V}$ indicate that all hamsters receiving MAb 2 or $3 \mathrm{~h}$ after challenge survived, whereas four of the five un-

Table V. Postexposure Rabies Treatment of Syrian Hamsters with Mouse MAb Cocktail

\begin{tabular}{cccc}
\hline MAb dose & $\begin{array}{c}\text { Time of treatment } \\
\text { after virus challenge }\end{array}$ & $\begin{array}{c}\text { Challenge virus } \\
\text { dilution }^{\ddagger}\end{array}$ & Morbidity \\
\hline$I U / K g$ & $h$ & & \\
1,550 & 3 & $1: 200$ & $0 / 5$ \\
1,550 & 36 & $1: 200$ & $1 / 5$ \\
150 & 2 & $1: 1,000$ & $0 / 5$ \\
0 & - & $1: 200$ & $4 / 5$ \\
0 & - & $1: 1,000$ & $4 / 5$
\end{tabular}

* MAb were administered intramuscularly.

${ }^{\ddagger}$ Hamsters were challenged intramuscularly with a suspension of dog salivary gland infected with the NYC strain of rabies virus. 
treated control animals succumbed to rabies infection. In hamsters treated with the MAb cocktail $36 \mathrm{~h}$ after infection, all but one of the five animals survived.

\section{Discussion}

Rabies virus-specific antibodies represent important factors in protective immunity against rabies. Rabies VNA have been considered the primary basis of effective protection against death in animals and humans from street rabies virus infection $(3,4)$. Therefore, antirabies serum as an adjunct to vaccination is an essential component in the prophylaxis of rabies after exposure. Because of the potential risks associated with the use of immune sera derived from animals and the high costs of HRIG, we have tested the usefulness of mouse anti-rabies MAbs. To obtain an activity spectrum comparable to that found in HRIG, we selected five MAbs, three of which recognize different epitopes on the rabies virus $G$ protein and neutralize rabies and rabies-related virus strains in vitro. We also included two RNP-specific MAbs in our MAb cocktail because in addition to VNA, nonneutralizing antibodies elicited by the RNP contribute to the protective immune response against a rabies virus infection (7). These RNP-specific antibodies may act in part by promoting the attachment of viral RNP via Fc receptors to phagocytic cells, which are then stimulated by the infecting virus to produce monokines (e.g., IFN) that can inhibit viral replication (7).

To determine the therapeutic effect against a lethal rabies virus infection, we treated mice with individual MAbs and the MAb cocktail. The results of these protection experiments in mice revealed that the individual $G$ protein-specific MAbs, as well as the MAb cocktail, are highly effective when administered before virus challenge. The individual antibodies differ significantly in their protective activity. Moreover, there is apparently no correlation between in vitro neutralizing activity and the protective activity in vivo, suggesting that mechanisms other than neutralization of extracellular virus are mediated by these antibodies. The observation that the protective activity of $F\left(a b^{\prime}\right)_{2}$ fragments is $>10$ times lower than that of the complete antibody supports the assumption that the protection conferred by MAbs is the result of a complex interaction of various immune effector mechanisms (6). The inconsistent correlation between the efficiency of virus neutralization in vitro by MAbs and animal protection has also been observed with foot-and-mouth disease virus (21). It was speculated that opsonization and subsequent rapid phagocytosis play a major role in the antibody-mediated immune defense against footand-mouth disease virus (21).

Protection experiments in hamsters demonstrated that the MAb cocktail is also highly effective in postexposure situations. Treatment of hamsters with 1,550 or $150 \mathrm{IU} / \mathrm{kg} \mathrm{MAb}$ cocktail resulted in complete protection from lethal rabies virus infection. Even when the MAbs were administered $36 \mathrm{~h}$ after infection, $80 \%$ of these animals survived, whereas $80 \%$ of the untreated control animals succumbed to rabies. These protection experiments suggest that a cocktail of several mouse MAbs may be of great use for the postexposure treatment of human rabies. Such a cocktail has several advantages over hyperimmune sera: $(a)$ The specific virus neutralizing activity and protective activity is much higher than that of HRIG; (b) based on protein content, only relatively small quantities of MAbs have to be injected; $(c)$ the use of MAbs may be superior for local wound treatment, where only small volumes can be inoculated at the bite site.

The disadvantages of mouse MAbs for therapeutic use in humans are such possible side effects as anaphylactic reactions and hypersensitization. However, mouse MAbs have been used extensively in the immunotherapy of patients with gastrointestinal adenocarcinoma (11), pancreatic adenocarcinoma (22), and colorectal carcinoma (23), and no or only mild and reversible $(11,24)$ immediate or delayed side effects, signs of toxicity, or serum sickness after the application of a single dose of mouse MAbs were observed in nonimmunosuppressed patients $(11,24,25)$. Most patients tolerated even the multiple applications well $(26,27)$. Thus, the number and severity of side effects caused by mouse MAbs can be assumed to be low, especially because only one dose of antibody is administered during postexposure treatment of rabies, and not for subsequent exposures. These data strongly suggest that murine anti-rabies MAbs should be given serious consideration as to their use in future rabies postexposure treatment.

\section{Acknowledgments}

We thank Leota Granger Terry, Georgia Krivulka, and Julia Dieter for their valuable technical assistance.

This work was supported by U. S. Public Health Service grant AI-09706-16 from the National Institute of Allergy and Infectious Diseases.

\section{References}

1. Steele, H. H. 1988. Rabies in the Americas and remarks on global aspects. Rev. Infect. Dis. 10(Suppl. 4):585-597.

2. Baer, G. M. 1988. Research towards rabies prevention: overview. Rev. Infect. Dis. 10(Suppl. 4):576-578.

3. Koprowski, H., J. Van Der Scheer, and J. Black. 1950. Use of hyperimmune anti-rabies serum concentrates in experimental rabies. Am. J. Med. 8:412-420.

4. Sikes, R. K., W. F. Clearly, H. Koprowski, T. J. Wiktor, and M. Kaplan. 1971. Effective protection of monkeys against death by street virus by post-exposure administration of tissue culture rabies vaccine. Bull. WHO. 45:1-11.

5. Davis, D. R., and H. Metzger. 1983. Structural basis of antibody function. Annu. Rev. Immunol. 1:87-147.

6. Celis, E., T. J. Wiktor, B. Dietzschold, and H. Koprowski. 1985. Amplification of rabies virus-induced stimulation of human T-cell lines and clones by antigen-specific antibody. $J$. Virol. 56:426-433.

7. Dietzschold, B., M. Gore, H. Ertl, E. Celis, L. Otvos, Jr., and H. Koprowski. 1989. Analysis of protective immune mechanisms induced by rabies nucleoprotein. In Genetics and Pathogenicity of Negative Strand Viruses. B. W. J. Mahy and D. Kalakowsky, editors. Elsevier Science Publishing Co., Inc., New York. 295-309.

8. Wilde, H., P. Chomchey, S. Prakongsri, P. Puyaratabandhu, and S. Chutivongse. 1989. Adverse effects of equine rabies immune globulin. Vaccine. 7:10-11.

9. Editorial. 1988. Rabies vaccine failures. Lancet. i:917-918.

10. Wilde, H., P. Choomkasien, T. Hemachudha, C. Supich, and S. Chutivongse. 1989. Failure of rabies postexposure treatment in Thailand. Vaccine. 7:49-52.

11. Sears, H., D. Herlyn, Z. Steplewski, and H. Koprowski. 1984. Effects of monoclonal antibody immunotherapy on patients with gastrointestinal adenocarcinoma. J. Biol. Resp. Mod. 3:138-150.

12. Turner, G. S. 1978. Immunoglobulin (IgG and IgM) antibody responses to rabies vaccine. J. Gen. Virol. 40:595-604.

13. Wiktor, T. J., B. Dietzschold, R. N. Leamnmson, and H. Koprowski. 1977. Induction and biological properties of defective interfering particles of rabies virus. $J$. Virol. 21:626-635. 
14. Wiktor, T. J., and H. Koprowski. 1978. Monoclonal antibodies against rabies virus produced by somatic cell hybridization detection of antigenic variants. Proc. Natl. Acad. Sci. USA. 75:3938-3942.

15. Hughes, E. N., and J. T. August. 1982. Murine cell surface glycoproteins: Identification, Purification and characterization of a major component of 110,000 Daltons by use of a monoclonal antibody. J. Biol. Chem. 257:3970-3977.

16. Nau, D. R. 1986. Rapid antibody purification: Bakerbond Abx. J. T. Baker Product Information Bulletin No. 8506. J. T. Baker Chemical Co., Philipsburg, NJ.

17. Chang, T. W., D. Testa, P. C. Kung, L. Perry, H. J. Dreskin, and G. Goldstain. 1982. Cellular origin and interactions involved in $\gamma$-interferon production induced by OKT3 monoclonal antibody. $J$. Immunol. 128:585-589.

18. Wiktor, T. J., R. I. Macfarlan, C. M. Foggin, and H. Koprowski. 1984. Antigenic analysis of rabies and Mokola virus from Zimbabwe using monoclonal antibodies. Dev. Biol. Stand. 57:199211.

19. Habel, K. 1966. Procedure for determining 50\% endpoints of Habel-type potency test in mice. In Laboratory Techniques in Rabies. 2nd ed. World Health Organization, Monograph Series No. 23. 142-143.

20. Dietzschold, B., C. E. Rupprecht, M. Tollis, M. Lafon, J. Mattei, T. J. Wiktor, and H. Koprowski. 1988. Antigenic diversity of the glycoprotein and nucleoprotein of rabies and rabies-related viruses: implications for epidemiology and control of rabies. Rev. Infect. Dis. 10(Suppl. 4):785-798.
21. McCullough, K. C., J. R. Crowther, R. N. Butcher, W. C. Carpenter, E. Brocchi, L. Capucci, and F. DeSimone. 1968. Immune protection against foot and mouth disease virus studied using virusneutralizing and non-neutralizing concentrations of monoclonal antibodies. Immunology. 57:421-428.

22. Sindelar, W. F., M. M. Maher, D. Herlyn, H. F. Sears, Z. Steplewski, and H. Koprowski. 1986. Trial of therapy of MAb 17-1A in pancreatic carcinoma: preliminary results. Hybridoma. 5(Suppl. 1):125-132.

23. Froedin, J. E., P. Biberfeld, B. Christensson, P. Philstedt, S. Sundelius, M. Sylvén, B. Wahren, H. Koprowski, and H. Mellstedt. 1986. Treatment of patients with metastasizing colo-rectal carcinoma with mouse monoclonal antibodies (Moab 17-1A): a progress report. Hybridoma. 5(Suppl. 1):151-151.

24. Sears, H., D. Herlyn, Z. Steplewski, and H. Koprowski. 1985. Phase-II clinical trial of a murine monoclonal antibody cytotoxic for gastrointestinal adenocarcinoma. Cancer Res. 45:5910-5913.

25. Sears, H., J. Mattis, D. Herlyn, P. Haevry, B. Atkinson, C. Ernst, Z. Steplewski, and H. Koprowski. 1982. Phase-I clinical trial of monoclonal antibody in treatment of gastrointestinal tumours. Lancet. i:762-765.

26. Lobuglio, A. F., M. Saleh, L. Peterson, R. Wheeler, R. Carrano, W. Huster, and M. B. Khazaeli. 1986. Phase 1 Clinical trial of CO17-1A monoclonal antibody. Hybridoma. 5(Suppl. 1):117-123.

27. Foon, K., R. Schroff, P. Bunn, D. Mayer, P. Abrams, M. Fer, J. Ochs, G. Bottino, S. Sherwin, D. Carlo, R. Heberman, and R. Oldham. 1984. Effects of monoclonal antibody therapy in patients with chronic lymphocytic leukemia. Blood. 64:1085-1093. 